\title{
Unlocking the Value of Anti-TNF Biosimilars: Reducing Disease Burden and Improving Outcomes in Chronic Immune-Mediated Inflammatory Diseases: A Narrative Review
}

\author{
Mourad F. Rezk · Burkhard Pieper
}

Received: June 10, 2020 / Published online: August 1, 2020

(C) The Author(s) 2020

Keywords: Access to treatment; Anti-TNF; Biosimilars; Disease burden; Early treatment; IMIDs; Maintenance of remission; Patient outcomes; Rheumatology

(IMIDs) are chronic conditions that create a significant disease burden on millions of patients while adding a major financial burden to societies and healthcare systems.

The introduction of biologic medicines has contributed majorly to improving the clinical outcomes of IMIDs and as such these modalities have gained first- or second-line positions in a wide range of treatment guidelines from different international clinical societies. However, the high cost of these biologics traditionally limited their accessibility and delayed their initiation, leaving millions of patients with unmet medical needs for a more affordable and sustainable solution.

The introduction of cost-efficient biosimilar anti-TNFs within Europe since 2013 has allowed more patients with IMIDs to access biologic therapies earlier and for longer, potentially altering the course of the disease into a milder phenotype and reducing the long-term disease burden. This review provides the latest evidence for the impact of biosimilars on patient outcomes and demonstrates their clinical value beyond a reduction in price.

Digital Features To view digital features for this article go to https://doi.org/10.6084/m9.figshare.12602219.

M. F. Rezk $(\bowtie) \cdot$ B. Pieper

Biogen International GmbH, Neuhofstrasse 30, 6340

Baar, Switzerland

e-mail: mouradfarouk.rezk@biogen.com

\section{Key Summary Points}

Over the past 2 decades anti-tumour necrosis factor (TNF) biologics have revolutionized the management of chronic immune-mediated inflammatory diseases, but their relatively high cost has created unequal access for patients to these effective treatments and compromised therapeutic goals

In addition to their positive impact on the sustainability of global healthcare, current evidence clearly shows that anti-TNF biosimilars are having an impact beyond cost reduction alone-increasing access to these essential biological therapies, improving patients' outcomes and reducing disease burden

However, all patients need to be able to take advantage of the full spectrum of benefits that biosimilars bring, which can be achieved by expeditious approvals, optimized market competition, and prompt and appropriate switching 


\section{INTRODUCTION}

Immune-mediated inflammatory diseases (IMIDs) are chronic conditions that share common pathophysiological pathways and include rheumatoid arthritis (RA), inflammatory bowel disease (IBD) and psoriasis (PsO) [1]. Globally, IMIDs have an incidence of $5-7 \%$ [2] and patients can often have multiple inflammatorydriven conditions at any one time [1]. Thus, IMIDs cause a large burden to patients, physicians and societies [1, 3-5].

The introduction of biologic drugs more than 2 decades ago revolutionized treatment across a number of IMIDs within rheumatology, dermatology and gastroenterology [6-9]. Key trials of biological therapies showed a large impact in reducing disease burden for the majority of patients [10-13]. This impressive efficacy, alongside manageable side effect profiles [14, 15], and improvements in patients' quality of life [16-18] led to biologics being recommended for use within society guidelines [19-30].

While biologics undoubtedly have a positive clinical impact, they are associated with high costs [31-33]. One report noted that out of an estimated global drug budget of US\$1 trillion in 2018, innovative biologics account for $29 \%$ (US\$296 billion) [34]. Another report found that, in the US market, spending on biologics totaled US\$125 billion in 2018, a 50\% increase since 2014 [35]. These high costs create new clinical unmet needs that disadvantage patients and healthcare professionals (HCPs) (Fig. 1). The arrival of biosimilars introduced lower cost biologics to the market, reducing healthcare spend and allowing subsequent savings to be reinvested into healthcare services [36-41]. Numerous modeling studies have predicted large-scale cost savings across Europe following biosimilar market entry (Table 1), which are now being realized [42]. However, the benefits of biosimilars reach beyond cost alone and can impact the unmet clinical needs associated with biologics. This article is based on previously conducted studies and does not contain any studies with human participants or animals performed by any of the authors.

\section{ACCESS TO TREATMENT}

While biologics are highly effective in treating IMIDs their high cost leads to their underutilization in many countries because of access restrictions [36, 39, 43-45]. A cross-sectional study across 46 European countries showed that many countries limited access through reimbursement criteria that were stricter than national and international guidelines [45]. In ten countries biologics were not reimbursed at all, and within the other 36 where at least one biologic was reimbursed, significant differences in eligibility criteria existed (requirement for more treatment failures, increased disease activity). Another study determined that while $32 \%$ of the total RA population in the European region is eligible for biologic treatment as defined by European League Against Rheumatism (EULAR) guidelines, only 59\% of this population remain eligible following the application of national reimbursement criteria (range 13-86\%) [39]. Furthermore, in some EU countries patients must make high co-payments that may lead to further inequities in the use of biologicals [46].

The introduction of cost-effective biosimilars across a wide range of therapeutic areas, including IMIDs, has lowered cost and increased the ability of patients to access biologic treatment [42]. Biosimilars to granulocyte colony-stimulating factor (GCSF) were the first biosimilars marketed. Following their introduction across Europe the cost of GCSF treatment decreased on average by $28 \%$, while the uptake increased, although it varied greatly from country to country increasing from $50 \%$ to $200 \%$ in Belgium, Demark, Ireland and the Netherlands to 300-1600\% in Poland, Romania, Slovakia and Slovenia in 2014 compared with year of biosimilar entry (2008) [47]. In Sweden, the introduction of biosimilar filgrastim reduced costs and resulted in a fivefold increase in GCSF uptake [48]. Finally, a recent review noted that the reduced costs and increased access that biosimilar pegfilgrastim affords could allow countries to switch from the shorter-acting filgrastim, improving adherence and enabling patients to receive their full 


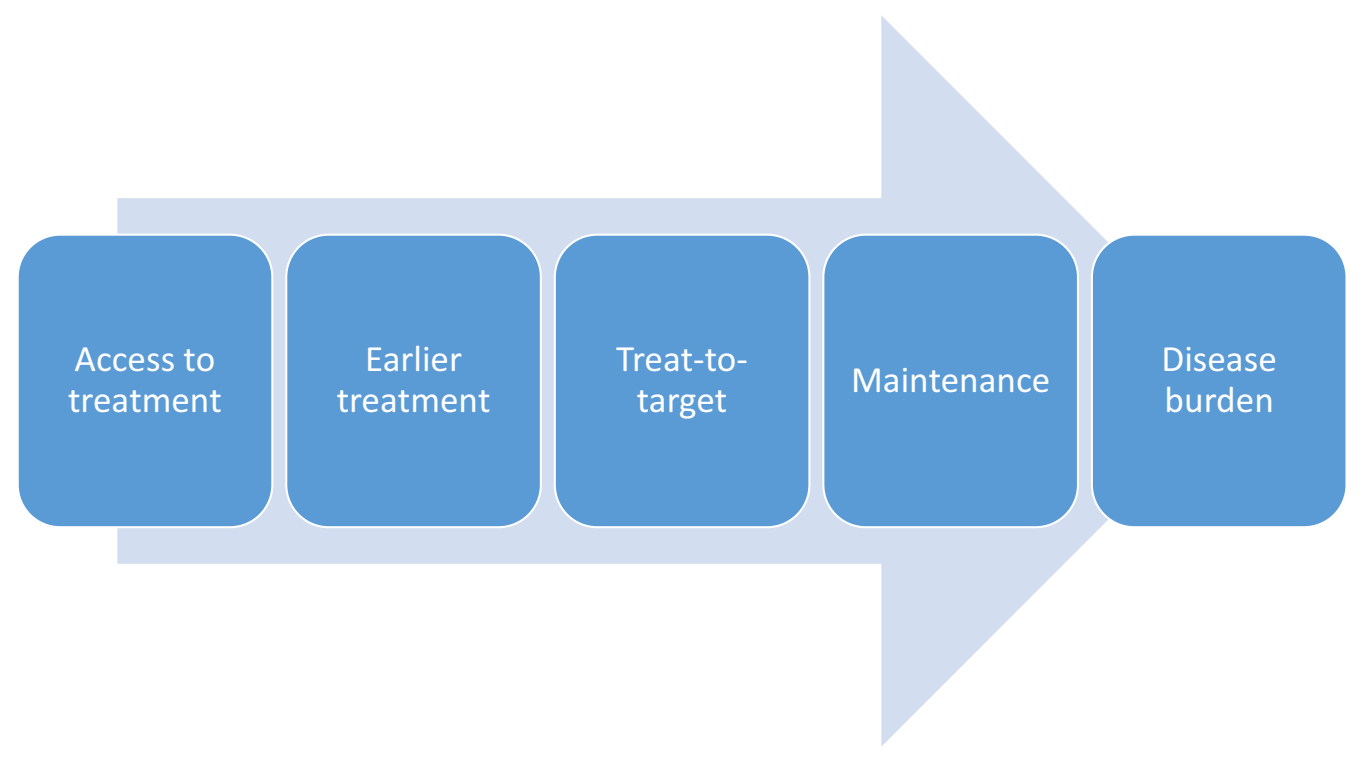

Fig. 1 Unmet clinical needs created by high costs of biological therapies in IMIDs

chemotherapy treatment, without dose delays or reduced dose intensities, improving patient outcomes [49].

The same effects have been observed for antiTNF biosimilars. Using data from the Swedish Rheumatology Quality Register, Di Giuseppe et al. [50] showed that introduction of biosimilars to infliximab (IFX) and etanercept (ETN) resulted in an increase of the total number of ongoing treatments (originator + biosimilar) during the study period from more than 125 patients/month before to more than 165 patients/month following the introduction of biosimilars. Similarly, Razanskaite et al. [51] demonstrated that at the same time that costs were reduced following IFX biosimilar introduction, the number of treatments went up from a maximum of 100,000 vials/month to 140,000 vials/month.

\section{EARLIER TREATMENT}

It is generally accepted that IMIDs should be treated effectively as early as possible to modify the natural progression of the disease, preventing target organ damage and limiting the occurrence and worsening of comorbid diseases-the so-called window of opportunity [52-56]. Delays in the assessment and treatment of patients with RA are associated with higher risks of not achieving remission, joint destructions and radiographic progression [57, 58]. Conversely, in a meta-analysis of 12 studies within RA, early treatment with diseasemodifying anti-rheumatic drugs (DMARDs) led to a significant $33 \%$ reduction in joint damage compared with patients treated later in the course of their disease [59]. These benefits of early treatment were observed for up to 5 years, and patients with aggressive disease (as measured by radiographic progression at baseline) appeared to derive more benefit than patients with less-aggressive disease. Benefits of earlier treatment have also been shown with biologics [60-68]. Earlier intervention with biologic treatment (IFX + MTX) provided higher shortand long-term remission rates in patients with Crohn's disease (CD) compared with conventional treatment without increasing serious adverse events [62]. In an analysis of health claims data from the USA, patients who received anti-TNF therapy early in their disease course (30 days within the first prescription for CD—the 'top down' approach) experienced lower risks of concomitant corticosteroid use, anti-TNF dose escalation, discontinuation/ switch of anti-TNF therapy, and CD-related surgery up to 24 months post therapy initiation compared with the 'step-up' approach 
Table 1 Potential savings as a result of biosimilar introduction within the EU

\begin{tabular}{|c|c|c|c|c|c|c|}
\hline References & Country & Therapy area & Biosimilars & Model & Projected saving & Additional patients treated \\
\hline $\begin{array}{l}\text { Aladul } \\
\text { et al. } \\
{[125]}\end{array}$ & UK & $\begin{array}{l}\text { Rheumatology } \\
\text { Gastroenterology }\end{array}$ & $\begin{array}{l}\text { Adalimumab } \\
\text { Etanercept } \\
\text { Infliximab }\end{array}$ & $\begin{array}{l}\text { Budget impact model } \\
\text { using retrospective } \\
\text { market shares of } \\
\text { biologics in } \\
\text { rheumatology and } \\
\text { gastroenterology }\end{array}$ & $\begin{array}{l}£ 44 \text { million over } \\
\text { next } 3 \text { years }\end{array}$ & \\
\hline $\begin{array}{l}\text { Jha et al. } \\
\qquad[126]\end{array}$ & $\begin{array}{l}\text { Belgium } \\
\text { Germany } \\
\text { Italy } \\
\text { Netherlands } \\
\text { UK }\end{array}$ & $\begin{array}{l}\text { Rheumatology } \\
\text { Gastroenterology } \\
\text { Dermatology }\end{array}$ & Infliximab & $\begin{array}{l}\text { Budget impact model } \\
\text { with a 1-year time } \\
\text { horizon }\end{array}$ & $\begin{array}{l}€ 25.79-77.37 \\
\text { million } \\
\text { depending on } \\
\text { country and } \\
\text { price discount }\end{array}$ & $\begin{array}{l}1960-7561 \text { across all five } \\
\text { countries }\end{array}$ \\
\hline $\begin{array}{c}\text { Brodszky } \\
\text { et al. } \\
\text { [127] }\end{array}$ & $\begin{array}{l}\text { Bulgaria } \\
\text { Czech } \\
\text { Republic } \\
\text { Hungary } \\
\text { Poland } \\
\text { Romania } \\
\text { Slovakia }\end{array}$ & Crohn's disease & Infliximab & $\begin{array}{l}\text { 3-year, prevalence-based } \\
\text { budget impact analysis }\end{array}$ & $\begin{array}{l}\text { Scenario 1: } \\
\text { interchanging } \\
\text { not allowed: } € 8 \\
\text { million } \\
\text { Scenario 2: } \\
\text { interchanging } \\
\text { allowed in } 80 \% \\
\text { patients: ca. } € 17 \\
\text { million }\end{array}$ & \\
\hline $\begin{array}{l}\text { Lee et al. } \\
\quad[128]\end{array}$ & $\begin{array}{l}28 \mathrm{EU} \\
\text { countries* }^{*}\end{array}$ & $\begin{array}{l}\text { Breast cancer } \\
\text { Gastric cancer }\end{array}$ & Trastuzumab & $\begin{array}{l}\text { Budget impact model } \\
\text { with time horizon of } \\
1-5 \text { years }\end{array}$ & $\begin{array}{l}€ 0.91-2.27 \text { billion } \\
\text { over } 5 \text { years } \\
\text { depending on } \\
\text { scenario } \\
\text { In the first year } \\
\text { only budget } \\
\text { savings ranged } \\
\text { from } € 58 \text { million } \\
\text { to } € 136 \text { million }\end{array}$ & $3503-7078$ \\
\hline $\begin{array}{l}\text { Gulacsi } \\
\text { et al. } \\
\text { [129] }\end{array}$ & $\begin{array}{l}28 \mathrm{EU} \\
\text { countries* }^{*}\end{array}$ & $\begin{array}{l}\text { Rheumatology } \\
\text { Cancer }\end{array}$ & Rituximab & 3-year base-case scenario & $\begin{array}{l}\text { Base-case scenario } \\
\text { (biosimilar } \\
\text { uptake } 30 \% \text {, cost } \\
70 \% \text { of } \\
\text { originator): } € 90 \\
\text { million } \\
\text { Second scenario } \\
\text { (biosimilar } \\
\text { uptake } 50 \% \text { ): } \\
€ 150 \text { million }\end{array}$ & $\begin{array}{l}\text { Over } 3 \text { years projected } \\
\text { budget savings were } € 570 \\
\text { million equating to } 47,695 \\
\text { additional patients able to } \\
\text { access rituximab }\end{array}$ \\
\hline
\end{tabular}

*Austria, Belgium, Bulgaria, Croatia, Cyprus, Czech Republic, Denmark, Estonia, Finland, France, Germany, Greece, Hungary, Ireland, Italy, Latvia, Lithuania, Luxembourg, Malta, Netherlands, Poland, Portugal, Romania, Slovakia, Slovenia, Spain, Sweden, UK 
(5-ASA \pm corticosteroids before starting antiTNFs) [65]. In a recent systematic review and meta-analysis of 47 publications totaling 18,471 patients with $\mathrm{CD}$, early treatment with biologics was associated with higher rates of clinical remission (OR 2.10, $p<0.00001$ ) or mucosal healing (OR 2.37, $p<0.00001)$ and lower relapse rates (OR 0.31, $p=0.003$ ) compared with later treatment in both clinical trial and real-world settings [67].

Despite the rationale and evidence for the earlier treatment of patients, the 'step-up' strategy remains widely used in clinical practice, delaying the introduction of effective biological DMARDs (bDMARDs), resulting in long-term damage and disease burden. In addition, the majority of international guidelines restrict the use of biologics to the second line, following a 'top-up' approach, starting with a conventional DMARD before moving onto a bDMARD once disease progresses or does not respond to therapy [19-21, 24, 26, 28-30, 69]. A further complication is that guidelines are often not followed in clinical practice [70-72]. Furthermore, the health economic data that reimbursement criteria are based upon may not be up to date, leading to misalignment between policy and practice $[73,74]$. Introducing biologics earlier in the disease course may reduce morbidity, hospitalizations and surgical interventions, therefore reducing disease burden and potentially reducing long-term costs [53, 54, 75-78].

The introduction of biosimilars could reduce the cost of therapy, allowing patients to be treated earlier in their disease course and more in line with guideline recommendations $[36,64]$. In 2016 the National Institute for Health and Care Excellence (NICE) provided a technology appraisal on the use of biologic drugs in RA (TA375) [73]. It concluded that biologics could only be used in RA patients with severe disease who had not responded to intensive therapy with combinations of DMARDs. NICE determined that biologic use could not be recommended at that time in patients with moderate disease as the incremental cost-effectiveness ratio (ICER) for this group of patients was $£ 10,000$ higher than that for those with severe disease [73]. However, in
January 2019, NICE took the decision to initiate a review of their recommendations within TA375 for patients with moderate disease because more cost-effective biosimilar versions of adalimumab, ETN and rituximab had become available that would improve the affordability of biologic treatment in patients with moderate disease [74]. Final recommendations are still pending. Availability of biosimilars has also had an impact on society guidelines. In the most recent EULAR guidelines on the use of DMARDs in patients with RA [27] the task force updated their recommendation from biologics being 'considered' to 'should be added' to conventional synthetic DMARDs (csDMARDs) for patients with poor prognostic factors. The guidelines also note that some members of the task force suggested applying a similar recommendation for patients who do not exhibit poor prognostic factors, but there was not sufficient support for this within the task force.

\section{ACHIEVEMENT AND MAINTENANCE OF REMISSION}

The principle of treat-to-target (T2T) has been successful in different therapeutic areas including hypertension [79] and diabetes [80], and is aimed at achieving a prompt and effective control of the disease process that is then maintained over time [70, 81]. Current guidelines and recommendations for IMIDs also recommend a treat-to-target approach [69, 82-84]. The value of such an approach is better patient outcomes in both the short and long term, which in addition to remission includes reductions in comorbidities and cardiovascular risk, as well as improvements in quality of life and productivity [81, 85-90]. However, several studies have shown that the practices outlined in guidelines do not translate well into the clinic with low rates of adherence to recommendations [70, 91-94]. Reasons for nonadherence include lack of awareness of guidelines, individual physician beliefs and financial and cost issues [91-93], including access to the relevant treatments as outlined earlier in the review. Several studies have shown that RA 
patients with moderate-to-severe disease receive biologics on a less frequent basis than recommended in guidelines (7-55\%) $[92,93,95]$ and also patients with more severe disease are more likely to be non-adherent to treatment [92]

While biologics have proven highly effective in inducing remission in patients with IMIDs [96-98] they have also been shown to be effective in maintaining remission [96, 99, 100]. However, the financial burden of biologic drugs has led to investigations of whether bDMARD therapy can be tapered or stopped in patients who have been in remission for a significant period of time [101, 102]. While some patients in remission can become biologic or drug free, stopping or tapering biological therapy in patients with IMIDs increases the risk of flares and relapse for a significant proportion of patients [103-112]. In one study 184 patients with moderate-to-severe psoriasis were retrospectively followed after clinical trials they had participated in had ended [107]. The study showed that $86 \%$ of patients required systemic treatment 12 months after biologic withdrawal, and biologics were reinitiated in $77 \%$ of patients by 3 years post withdrawal. In an interim analysis of a randomized controlled trial of patients with RA $(n=101)$ in stable remission, over half of patients remained in remission following reduction in or stopping of csDMARD or bDMARD therapy [106]. However, one-third of patients relapsed with both tapering $(\mathrm{OR}=$ 5.74, $p<0.05)$ and stopping therapy $(\mathrm{OR}=$ $8.78, p<0.01)$, which were significantly predictive of relapse in a multivariate logistical regression analysis. In a UK-based observational study relapse rates following withdrawal of antiTNF therapy in patients with IBD were ca. $40 \%$ and ca. $50 \%$ at 1 year and 2 years post withdrawal for both CD and ulcerative colitis (UC) cohorts. A systematic review and meta-analysis by the same group confirmed 1-year relapse rates of ca. $40 \%$. Reinitiation of anti-TNF therapy was successful in the majority of patients. Thus, while dose-reducing strategies can be successful for a subset of patients, they expose others to increased disease burden and reduced quality of life. Possible prognostic factors are being investigated to allow the identification of which patients are at higher risk of relapse following treatment withdrawal/tapering [110, 113-116]. Younger age at diagnosis and more extensive and aggressive disease are indicators for continued therapy [113].

The more cost-effective nature of biosimilars will allow patients to be treated to target and then to be maintained on the most ideal regimen based on their risk factors and personal needs. Patients deemed to be at risk of relapse can remain on therapy when in remission or experiencing low-disease activity, thus improving outcomes and reducing clinical and personal burden.

\section{DISEASE BURDEN}

As described earlier, IMIDs share common inflammatory pathways [1] and therefore it might be assumed that having one IMID might make a person more prone to other inflammatory diseases. This is indeed the case. In a systematic review and meta-analysis of 25 publications, Schieir et al. [117] noted an increased risk of myocardial infarction (MI) across IMIDs with a $69 \%$ increased risk in RA and a $41 \%$ increased risk in psoriatic arthritis. These risks remained following adjustment for more traditional risk factors for MI. Increased cardiovascular risk has also been noted in patients with PsO [118]. The presence of one IMID also puts patients at higher risk of other IMIDs. A recent retrospective matched cohort study showed that the presence of one IMID puts patients at $5-62 \%$ increased risk of developing an additional IMID and at 3-75\% increased risk of another two IMIDs [119]. Patients with IBD have been noted to be at higher risk of developing psoriasis, RA, ankylosing spondylitis (AS), multiple sclerosis (MS) and asthma [120-123]. Conversely the risk of IBD is increased in patients with PsO [118]. In two large studies (one EU, one US) approximately $22 \%$ of patients with IBD had at least one other immune-mediated disease [121, 123]. The presence of another IMID increases disease burden by increasing the risk of surgery and decreasing disease-specific and general physical quality of life $[121,123]$. However, treatment of the primary IMID with anti-TNFa therapies 
reduces the risk and impact of secondary IMIDs, therefore further reducing the burden on the patient $[2,121,124]$. Patients with IBD treated with infliximab had a 50\% reduced risk of developing secondary IMIDs [121], while the risk of MI in patients with $\mathrm{PsO}$ was also reduced $50 \%$ by the use of anti-TNFa inhibitors for 2 months or longer [124].

\section{CONCLUSIONS}

Along the course of the last 2 decades, TNF inhibitors, particularly etanercept, infliximab and adalimumab, have revolutionized the management of chronic immune-mediated inflammatory diseases; however, their relatively high cost prevented healthcare systems from exploiting their full clinical benefit.

The introduction of anti-TNF biosimilars into clinical practice continues to have a large impact on the sustainability of global healthcare. As more real-world evidence on their use is accruing, it is also clear that the impact of antiTNF biosimilars expands beyond that of cost reduction alone and can increase patients' access to these essential biological therapies and positively influence the course of their disease $[36,50,51]$. This includes the opportunity to realize clinical goals such as early initiation of biological treatment, treating to target, continuing treatment to maintain remission or low disease activity and reducing disease burden. However, for the true benefit of biosimilar antiTNFs to be realized, the right environment needs to be created, one where high-quality biosimilars are approved expeditiously, competition for a given originator is optimized and the switching of patients onto biosimilars is properly enabled. All of these actions will result in maximum cost savings [125], which can then be reinvested into patient care.

Acceptance of anti-TNF biosimilars across healthcare system stakeholders would allow more equitable access to these highly effective and cost-sensitive therapies and enable optimized management of chronic IMIDs.

\section{ACKNOWLEDGEMENTS}

Funding. This review, the Rapid Service and Open Access Fees were funded by Biogen International $\mathrm{GmbH}$.

Editorial Assistance. Editorial assistance in the preparation of this manuscript was provided by Iain Bartlett of Springer Healthcare Ltd. Funding for this assistance was provided by Biogen International GmbH, Baar, Switzerland.

Authorship. All named authors meet the International Committee of Medical Journal Editors (ICMJE) criteria for authorship for this article, take responsibility for the integrity of the work as a whole, and have given their approval for this version to be published.

Authorship Contributions. All authors contributed to the creation and critical review of the manuscript. All authors have approved the final version of the manuscript.

Disclosures. Mourad F. Rezk and Burkhard Pieper are employees of Biogen International $\mathrm{GmbH}$ and may hold stock in Biogen.

Compliance with Ethics Guidelines. This article is based on previously conducted studies and does not contain any studies with human participants or animals performed by any of the authors.

Open Access. This article is licensed under a Creative Commons Attribution-NonCommercial 4.0 International License, which permits any non-commercial use, sharing, adaptation, distribution and reproduction in any medium or format, as long as you give appropriate credit to the original author(s) and the source, provide a link to the Creative Commons licence, and indicate if changes were made. The images or other third party material in this article are included in the article's Creative Commons licence, unless indicated otherwise in a credit line to the material. If material is not included in the article's Creative Commons licence and your intended use is not permitted by statutory 
regulation or exceeds the permitted use, you will need to obtain permission directly from the copyright holder. To view a copy of this licence, visit http://creativecommons.org/licenses/by$\mathrm{nc} / 4.0 /$.

\section{REFERENCES}

1. Kuek A, Hazleman BL, Ostor AJ. Immune-mediated inflammatory diseases (IMIDs) and biologic therapy: a medical revolution. Postgrad Med J. 2007;83(978):251-60. https://doi.org/10.1136/ pgmj.2006.052688.

2. El-Gabalawy H, Guenther LC, Bernstein CN. Epidemiology of immune-mediated inflammatory diseases: incidence, prevalence, natural history, and comorbidities. J Rheumatol Suppl. 2010;85:2-10. https://doi.org/10.3899/jrheum.091461.

3. Burisch J, Jess T, Martinato M, Lakatos PL, EpiCom E. The burden of inflammatory bowel disease in Europe. J Crohns Colitis. 2013;7(4):322-37. https:// doi.org/10.1016/j.crohns.2013.01.010.

4. Griffiths CEM, Jo SJ, Naldi L, et al. A multidimensional assessment of the burden of psoriasis: results from a multinational dermatologist and patient survey. Br J Dermatol. 2018;179(1):173-81. https:// doi.org/10.1111/bjd.16332.

5. Jacobs P, Bissonnette R, Guenther LC. Socioeconomic burden of immune-mediated inflammatory diseases-focusing on work productivity and disability. J Rheumatol Suppl. 2011;88:55-61. https://doi.org/10.3899/jrheum.110901.

6. Cote-Daigneault J, Bouin M, Lahaie R, Colombel JF, Poitras P. Biologics in inflammatory bowel disease: what are the data? United Eur Gastroenterol J. 2015;3(5):419-28. https://doi.org/10.1177/20506 40615590302 .

7. Law ST, Taylor PC. Role of biological agents in treatment of rheumatoid arthritis. Pharmacol Res. 2019;150:104497. https://doi.org/10.1016/j.phrs. 2019.104497.

8. Rein P, Mueller RB. Treatment with biologicals in rheumatoid arthritis: an overview. Rheumatol Ther. 2017;4(2):247-61. https://doi.org/10.1007/s40744017-0073-3.

9. Ronholt K, Iversen L. Old and new biological therapies for psoriasis. Int J Mol Sci. 2017;18:2297. https://doi.org/10.3390/ijms18112297.
10. Leonardi CL, Romiti R, Tebbey PW. Ten years on: the impact of biologics on the practice of dermatology. Dermatol Clin. 2015;33(1):111-25. https:// doi.org/10.1016/j.det.2014.09.009.

11. Menter A, Tyring SK, Gordon K, et al. Adalimumab therapy for moderate to severe psoriasis: a randomized, controlled phase III trial. J Am Acad Dermatol. 2008;58(1):106-15. https://doi.org/10. 1016/j.jaad.2007.09.010.

12. Moreland LW, Schiff MH, Baumgartner SW, et al. Etanercept therapy in rheumatoid arthritis. A randomized, controlled trial. Ann Intern Med. 1999;130(6):478-86. https://doi.org/10.7326/00034819-130-6-199903160-00004.

13. Weinblatt ME, Kremer JM, Bankhurst AD, et al. A trial of etanercept, a recombinant tumor necrosis factor receptor: Fc fusion protein, in patients with rheumatoid arthritis receiving methotrexate. N Engl J Med. 1999;340(4):253-9. https://doi.org/10.1056/ NEJM199901283400401.

14. Nurmohamed M, Choy E, Lula S, Kola B, DeMasi R, Accossato P. The impact of biologics and tofacitinib on cardiovascular risk factors and outcomes in patients with rheumatic disease: a systematic literature review. Drug Saf. 2018;41(5):473-88. https:// doi.org/10.1007/s40264-017-0628-9.

15. Ruderman EM. Overview of safety of non-biologic and biologic DMARDs. Rheumatology (Oxford). 2012;51(Suppl 6):vi37-43. https://doi.org/10.1093/ rheumatology/kes283.

16. Iskandar IYK, Ashcroft DM, Warren RB, et al. Comparative effectiveness of biological therapies on improvements in quality of life in patients with psoriasis. Br J Dermatol. 2017;177(5):1410-21. https://doi.org/10.1111/bjd.15531.

17. LeBlanc K, Mosli MH, Parker CE, MacDonald JK. The impact of biological interventions for ulcerative colitis on health-related quality of life. Cochrane Database Syst Rev. 2015:CD008655. https://doi.org/ 10.1002/14651858.cd008655.pub3.

18. Strand V, Singh JA. Newer biological agents in rheumatoid arthritis: impact on health-related quality of life and productivity. Drugs. 2010;70(2): 121-45. https://doi.org/10.2165/11531980-00000 0000-00000.

19. Gossec L, Smolen JS, Ramiro S, et al. European League Against Rheumatism (EULAR) recommendations for the management of psoriatic arthritis with pharmacological therapies: 2015 update. Ann Rheum Dis. 2016;75(3):499-510. https://doi.org/10. 1136/annrheumdis-2015-208337. 
20. Harbord M, Eliakim R, Bettenworth D, et al. Third European evidence-based consensus on diagnosis and management of ulcerative colitis. Part 2: current management. J Crohns Colitis. 2017;11(7): 769-84. https://doi.org/10.1093/ecco-jcc/jjx009.

21. Lichtenstein GR, Loftus EV, Isaacs KL, Regueiro MD, Gerson LB, Sands BE. ACG clinical guideline: management of Crohn's disease in adults. Am J Gastroenterol. 2018;113(4):481-517. https://doi.org/ 10.1038/ajg.2018.27.

22. Menter A, Strober BE, Kaplan DH, et al. Joint AADNPF guidelines of care for the management and treatment of psoriasis with biologics. J Am Acad Dermatol. 2019;80(4):1029-72. https://doi.org/10. 1016/j.jaad.2018.11.057.

23. Nast A, Gisondi P, Ormerod AD, et al. European S3Guidelines on the systemic treatment of psoriasis vulgaris-update 2015-short version-EDF in cooperation with EADV and IPC. J Eur Acad Dermatol Venereol. 2015;29(12):2277-94. https://doi.org/10. $1111 / j d v .13354$.

24. Rubin DT, Ananthakrishnan AN, Siegel CA, Sauer BG, Long MD. ACG clinical guideline: ulcerative colitis in adults. Am J Gastroenterol. 2019;114(3): $384-413$. 0000000000000152 .

25. Singh JA, Guyatt G, Ogdie A, et al. Special article: 2018 American College of Rheumatology/National Psoriasis Foundation guideline for the treatment of psoriatic arthritis. Arthritis Rheumatol. 2019;71(1): 5-32. https://doi.org/10.1002/art.40726.

26. Singh JA, Saag KG, Bridges SL Jr, et al. 2015 American College of Rheumatology guideline for the treatment of rheumatoid arthritis. Arthritis Rheumatol. 2016;68(1):1-26. https://doi.org/10. 1002/art.39480.

27. Smolen JS, Landewe RBM, Bijlsma JWJ, et al. EULAR recommendations for the management of rheumatoid arthritis with synthetic and biological diseasemodifying antirheumatic drugs: 2019 update. Ann Rheum Dis. 2020;79(6):685-99. https://doi.org/10. 1136/annrheumdis-2019-216655.

28. Torres J, Bonovas S, Doherty G, et al. ECCO guidelines on therapeutics in Crohn's disease: medical treatment. J Crohns Colitis. 2020;14(1):4-22. https://doi.org/10.1093/ecco-jcc/jjz180.

29. van der Heijde D, Ramiro S, Landewe R, et al. 2016 update of the ASAS-EULAR management recommendations for axial spondyloarthritis. Ann Rheum Dis. 2017;76(6):978-91. https://doi.org/10.1136/ annrheumdis-2016-210770.
30. Ward MM, Deodhar A, Gensler LS, et al. 2019 Update of the American College of Rheumatology/ Spondylitis Association of America/Spondyloarthritis Research and Treatment Network recommendations for the treatment of ankylosing spondylitis and nonradiographic axial spondyloarthritis. Arthritis Rheumatol. 2019;71(10): 1599-613. https://doi.org/10.1002/art.41042.

31. Nurmohamed MT, Dijkmans BA. Efficacy, tolerability and cost effectiveness of disease-modifying antirheumatic drugs and biologic agents in rheumatoid arthritis. Drugs. 2005;65(5):661-94. https://doi.org/10.2165/00003495-20056505000006.

32. Pillai N, Dusheiko M, Burnand B, Pittet V. A systematic review of cost-effectiveness studies comparing conventional, biological and surgical interventions for inflammatory bowel disease. PLoS One. 2017;12(10):e0185500. https://doi.org/10. 1371/journal.pone.0185500.

33. van der Velde G, Pham B, Machado M, et al. Costeffectiveness of biologic response modifiers compared to disease-modifying antirheumatic drugs for rheumatoid arthritis: a systematic review. Arthritis Care Res (Hoboken). 2011;63(1):65-78. https://doi. org/10.1002/acr.20338.

34. IQVIA. Global, European and Belgian pharmaceutical market trends. 2019. Available from: https:// www.cib-pharma.be/uploads/global-european-andbelgian-pharmaceutical-market-trends-2019-final 1552840137.pdf. Accessed 4 May 2020.

35. Gottlieb S. Don't give up on biosimilars-congress can give them a boost: drugs grown in live cells are hard to replicate. But policy changes can help accelerate the process. Am Health Drug Benefits. 2019;12(5):252-3.

36. Baumgart DC, Misery L, Naeyaert S, Taylor PC. Biological therapies in immune-mediated inflammatory diseases: can biosimilars reduce access inequities? Front Pharmacol. 2019;10:279. https:// doi.org/10.3389/fphar.2019.00279.

37. Dutta B, Huys I, Vulto AG, Simoens S. Identifying key benefits in European off-patent biologics and biosimilar markets: it is not only about price! BioDrugs. 2020;34(2):159-70. https://doi.org/10.1007/ s40259-019-00395-w.

38. Inotai A, Csanadi M, Petrova G, et al. Patient access, unmet medical need, expected benefits, and concerns related to the utilisation of biosimilars in Eastern European countries: a survey of experts. Biomed Res Int. 2018;2018:9597362. https://doi. org/10.1155/2018/9597362. 
39. Kalo Z, Voko Z, Ostor A, et al. Patient access to reimbursed biological disease-modifying antirheumatic drugs in the European region. J Mark Access Health Policy. 2017;5(1):1345580. https://doi.org/ 10.1080/20016689.2017.1345580.

40. McBride A, Balu S, Campbell K, Bikkina M, MacDonald K, Abraham I. Expanded access to cancer treatments from conversion to neutropenia prophylaxis with biosimilar filgrastim-sndz. Future Oncol. 2017;13(25):2285-95. https://doi.org/10. 2217/fon-2017-0374.

41. Uhlig T, Goll GL. Reviewing the evidence for biosimilars: key insights, lessons learned and future horizons. Rheumatology (Oxford). 2017;56(suppl_ 4):iv49-62. https://doi.org/10.1093/rheumatology/ kex276.

42. IQVIA. The impact of biosimilar competition in Europe. 2018. https://ec.europa.eu/docsroom/ documents/31642. Accessed 4 May 2020.

43. Bergstra SA, Branco JC, Vega-Morales D, et al. Inequity in access to bDMARD care and how it influences disease outcomes across countries worldwide: results from the METEOR-registry. Ann Rheum Dis. 2018;77(10):1413-20. https://doi.org/ 10.1136/annrheumdis-2018-213289.

44. Pentek M, Lakatos PL, Oorsprong T, et al. Access to biologicals in Crohn's disease in ten European countries. World J Gastroenterol. 2017;23(34): 6294-305. https://doi.org/10.3748/wjg.v23.i34. 6294.

45. Putrik P, Ramiro S, Kvien TK, et al. Inequities in access to biologic and synthetic DMARDs across 46 European countries. Ann Rheum Dis. 2014;73(1): 198-206. https://doi.org/10.1136/annrheumdis2012-202603.

46. Kawalec P, Stawowczyk E, Tesar T, et al. Pricing and reimbursement of biosimilars in central and Eastern European countries. Front Pharmacol. 2017;8:288. https://doi.org/10.3389/fphar.2017.00288.

47. Zielinska J, Baialik W. Recent changes on the biopharmaceutical market after the introduction of biosimilar G-CSF products. Oncol Clin Pract. 2016;12:144-52.

48. Gascon P, Tesch H, Verpoort K, et al. Clinical experience with Zarzio ${ }^{\circledR}$ in Europe: what have we learned? Support Care Cancer. 2013;21(10): 2925-32. https://doi.org/10.1007/s00520-013-19117.

49. Cornes P, Gascon P, Vulto AG, Aapro M. Biosimilar pegfilgrastim: improving access and optimising practice to supportive care that enables cure.
BioDrugs. 2020;34(3):255-63. https://doi.org/10. 1007/s40259-020-00411-4.

50. Di Giuseppe D, Frisell T, Ernestam S, et al. Uptake of rheumatology biosimilars in the absence of forced switching. Expert Opin Biol Ther. 2018;18(5): 499-504. https://doi.org/10.1080/14712598.2018. 1458089.

51. Razanskaite V, Bettey M, Downey L, et al. Biosimilar infliximab in inflammatory bowel disease: outcomes of a managed switching programme. J Crohns Colitis. 2017;11(6):690-6. https://doi.org/ 10.1093/ecco-jcc/jjw216.

52. Breedveld FC, Kalden JR. Appropriate and effective management of rheumatoid arthritis. Ann Rheum Dis. 2004;63(6):627-33. https://doi.org/10.1136/ ard.2003.011395.

53. Kang B, Choe YH. Early biologic treatment in pediatric Crohn's disease: catching the therapeutic window of opportunity in early disease by treat-totarget. Pediatr Gastroenterol Hepatol Nutr. 2018;21(1):1-11. https://doi.org/10.5223/pghn. 2018.21.1.1.

54. Monti S, Montecucco C, Bugatti S, Caporali R. Rheumatoid arthritis treatment: the earlier the better to prevent joint damage. RMD Open. 2015;1(Suppl 1):e000057. https://doi.org/10.1136/ rmdopen-2015-000057.

55. Nagy G, van Vollenhoven RF. Sustained biologicfree and drug-free remission in rheumatoid arthritis, where are we now? Arthritis Res Ther. 2015;17: 181. https://doi.org/10.1186/s13075-015-0707-1.

56. Quinn MA, Emery P. Window of opportunity in early rheumatoid arthritis: possibility of altering the disease process with early intervention. Clin Exp Rheumatol. 2003;21(5 Suppl 31):S154-7.

57. van der Linden MP, le Cessie S, Raza K, et al. Longterm impact of delay in assessment of patients with early arthritis. Arthritis Rheum. 2010;62(12): 3537-46. https://doi.org/10.1002/art.27692.

58. van Nies JA, Tsonaka R, Gaujoux-Viala C, Fautrel B, van der Helm-van Mil AH. Evaluating relationships between symptom duration and persistence of rheumatoid arthritis: does a window of opportunity exist? Results on the Leiden early arthritis clinic and ESPOIR cohorts. Ann Rheum Dis. 2015;74(5): 806-12. https://doi.org/10.1136/annrheumdis2014-206047.

59. Finckh A, Liang MH, van Herckenrode CM, de Pablo P. Long-term impact of early treatment on radiographic progression in rheumatoid arthritis: a metaanalysis. Arthritis Rheum. 2006;55(6):864-72. https://doi.org/10.1002/art.22353. 
60. Baranauskaite A, Raffayova $\mathrm{H}$, Kungurov NV, et al. Infliximab plus methotrexate is superior to methotrexate alone in the treatment of psoriatic arthritis in methotrexate-naive patients: the RESPOND study. Ann Rheum Dis. 2012;71(4): 541-8. https://doi.org/10.1136/ard.2011.152223.

61. Colombel JF, Sandborn WJ, Reinisch W, et al. Infliximab, azathioprine, or combination therapy for Crohn's disease. N Engl J Med. 2010;362(15): 1383-95. https://doi.org/10.1056/NEJMoa0904492.

62. D'Haens G, Baert F, van Assche G, et al. Early combined immunosuppression or conventional management in patients with newly diagnosed Crohn's disease: an open randomised trial. Lancet. 2008;371(9613):660-7. https://doi.org/10.1016/ S0140-6736(08)60304-9.

63. Emery P, Breedveld FC, Hall S, et al. Comparison of methotrexate monotherapy with a combination of methotrexate and etanercept in active, early, moderate to severe rheumatoid arthritis (COMET): a randomised, double-blind, parallel treatment trial. Lancet. 2008;372(9636):375-82. https://doi.org/10. 1016/S0140-6736(08)61000-4.

64. Kavanaugh A, Keystone E, Greenberg JD, et al. Benefit of biologics initiation in moderate versus severe rheumatoid arthritis: evidence from a United States registry. Rheumatology (Oxford). 2017;56(7): 1095-101. https://doi.org/10.1093/rheumatology/ kex042.

65. Rubin DT, Uluscu O, Sederman R. Response to biologic therapy in Crohn's disease is improved with early treatment: an analysis of health claims data. Inflamm Bowel Dis. 2012;18(12):2225-31. https://doi.org/10.1002/ibd.22925.

66. St Clair EW, van der Heijde DM, Smolen JS, et al. Combination of infliximab and methotrexate therapy for early rheumatoid arthritis: a randomized, controlled trial. Arthritis Rheum. 2004;50(11): 3432-43. https://doi.org/10.1002/art.20568.

67. Ungaro RC, Aggarwal S, Topaloglu O, Lee WJ, Clark $\mathrm{R}$, Colombel JF. Systematic review and meta-analysis: efficacy and safety of early biologic treatment in adult and paediatric patients with Crohn's disease. Aliment Pharmacol Ther. 2020;51(9):831-42. https://doi.org/10.1111/apt.15685.

68. van der Kooij SM, le Cessie S, Goekoop-Ruiterman $\mathrm{YP}$, et al. Clinical and radiological efficacy of initial vs delayed treatment with infliximab plus methotrexate in patients with early rheumatoid arthritis. Ann Rheum Dis. 2009;68(7):1153-8. https://doi.org/10.1136/ard.2008.093294.

69. Smolen JS, Landewe R, Bijlsma J, et al. EULAR recommendations for the management of rheumatoid arthritis with synthetic and biological diseasemodifying antirheumatic drugs: 2016 update. Ann Rheum Dis. 2017;76(6):960-77. https://doi.org/10. 1136/annrheumdis-2016-210715.

70. Batko B, Batko K, Krzanowski M, Zuber Z. Physician adherence to treat-to-target and practice guidelines in rheumatoid arthritis. J Clin Med. 2019;8(9):1416. https://doi.org/10.3390/jcm8091416.

71. Jackson BD, Con D, Liew D, De Cruz P. Clinicians' adherence to international guidelines in the clinical care of adults with inflammatory bowel disease. Scand J Gastroenterol. 2017;52(5):536-42. https:// doi.org/10.1080/00365521.2017.1278785.

72. Lesuis N, den Broeder AA, Hulscher ME, van Vollenhoven RF. Practice what you preach? An exploratory multilevel study on rheumatoid arthritis guideline adherence by rheumatologists. RMD Open. 2016;2(1):e000195. https://doi.org/10.1136/ rmdopen-2015-000195.

73. National Institute for Health and Care Excellence. Adalimumab, etanercept, infliximab, certolizumab pegol, golimumab, tocilizumab and abatacept for rheumatoid arthritis not previously treated with DMARDs or after conventional DMARDs only have failed. Technology appraisal guidance, 26 January 2016. https://www.nice.org.uk/guidance/ta375/ resources/adalimumab-etanercept-infliximab-certoli zumab-pegol-golimumab-tocilizumab-and-abataceptfor-rheumatoid-arthritis-not-previously-treated-withdmards-or-after-conventional-dmards-only-havefailed-pdf-82602790920133. Accessed 4 May 2020.

74. National Institute for Health and Care Excellence. Review of TA375; Adalimumab, etanercept, infliximab, certolizumab pegol, golimumab, tocilizumab and abatacept for rheumatoid arthritis not previously treated with DMARDs or after conventional DMARDs only have failed. Technology appraisal review proposal paper. January 2019. https://www. nice.org.uk/guidance/ta375/resources/ consultation-review-may-2019-pdf8786049415621. Accessed 4 May 2020.

75. Haugeberg G, Boyesen P, Helgetveit K, Proven A. Clinical and radiographic outcomes in patients diagnosed with early rheumatoid arthritis in the first years of the biologic treatment era: a 10-year prospective observational study. J Rheumatol. 2015;42(12):2279-87. https://doi.org/10.3899/ jrheum.150384.

76. Mao EJ, Hazlewood GS, Kaplan GG, Peyrin-Biroulet L, Ananthakrishnan AN. Systematic review with meta-analysis: comparative efficacy of immunosuppressants and biologics for reducing hospitalisation and surgery in Crohn's disease and ulcerative 
colitis. Aliment Pharmacol Ther. 2017;45(1):3-13. https://doi.org/10.1111/apt.13847.

77. Nam JL, Emery P. Is there a place for initial treatment with biological DMARDs in the early phase of RA? Best Pract Res Clin Rheumatol. 2013;27:537-54. https://doi.org/10.1016/j.berh.2013.09.003

78. Patel D, Shelbaya A, Cheung R, Aggarwal J, Park SH, Coindreau J. Cost-effectiveness of early treatment with originator biologics or their biosimilars after methotrexate failure in patients with established rheumatoid arthritis. Adv Ther. 2019;36(8): 2086-95. https://doi.org/10.1007/s12325-01900986-7.

79. Verdecchia P, Staessen JA, Angeli F, et al. Usual versus tight control of systolic blood pressure in non-diabetic patients with hypertension (CardioSis): an open-label randomised trial. Lancet. 2009;374(9689):525-33. https://doi.org/10.1016/ S0140-6736(09)61340-4.

80. Nathan DM, Cleary PA, Backlund JY, et al. Intensive diabetes treatment and cardiovascular disease in patients with type 1 diabetes. $\mathrm{N}$ Engl J Med. 2005;353(25):2643-53. https://doi.org/10.1056/ NEJMoa052187.

81. van Vollenhoven R. Treat-to-target in rheumatoid arthritis-are we there yet? Nat Rev Rheumatol. 2019;15(3):180-6. https://doi.org/10.1038/s41584019-0170-5.

82. Armstrong AW, Siegel MP, Bagel J, et al. From the Medical Board of the National Psoriasis Foundation: treatment targets for plaque psoriasis. J Am Acad Dermatol. 2017;76(2):290-8. https://doi.org/10. 1016/j.jaad.2016.10.017.

83. Drescher H, Lissoos T, Hajisafari E, Evans ER. Treatto-target approach in inflammatory bowel disease: the role of advanced practice providers. J Nurse Pract. 2019;15:676-81. https://doi.org/10.1016/j. nurpra.2019.07.015

84. Smolen JS, Breedveld FC, Burmester GR, et al. Treating rheumatoid arthritis to target: 2014 update of the recommendations of an international task force. Ann Rheum Dis. 2016;75(1):3-15. https://doi. org/10.1136/annrheumdis-2015-207524.

85. Grigor C, Capell H, Stirling A, et al. Effect of a treatment strategy of tight control for rheumatoid arthritis (the TICORA study): a single-blind randomised controlled trial. Lancet. 2004;364 (9430):263-9. https://doi.org/10.1016/S0140-6736 (04)16676-2.

86. Hughes CD, Scott DL, Ibrahim F, TITRATE Programme Investigators. Intensive therapy and remissions in rheumatoid arthritis: a systematic review. BMC Musculoskelet Disord. 2018;19(1):389. https://doi.org/10.1186/s12891-018-2302-5.

87. Merola JF, Perez Chada L, Siegel M, et al. The National Psoriasis Foundation psoriasis treatment targets in real world patients: prevalence and association with patient reported outcomes in the Corrona Psoriasis Registry. J Eur Acad Dermatol Venereol. 2020. https://doi.org/10.1111/jdv.16274.

88. Schipper LG, van Hulst LT, Grol R, van Riel PL, Hulscher ME, Fransen J. Meta-analysis of tight control strategies in rheumatoid arthritis: protocolized treatment has additional value with respect to the clinical outcome. Rheumatology (Oxford). 2010;49(11):2154-64. https://doi.org/10.1093/ rheumatology/keq195.

89. Stoffer MA, Schoels MM, Smolen JS, et al. Evidence for treating rheumatoid arthritis to target: results of a systematic literature search update. Ann Rheum Dis. 2016;75(1):16-22. https://doi.org/10.1136/ annrheumdis-2015-207526.

90. Ten Klooster PM, Oude Voshaar MAH, Fakhouri W, de la Torre I, Nicolay C, van de Laar M. Long-term clinical, functional, and cost outcomes for early rheumatoid arthritis patients who did or did not achieve early remission in a real-world treat-totarget strategy. Clin Rheumatol. 2019;38(10):2727-36. https://doi.org/10.1007/s10067-019-04600-7.

91. Gvozdenovic E, Allaart CF, van der Heijde D, et al. When rheumatologists report that they agree with a guideline, does this mean that they practise the guideline in clinical practice? Results of the international recommendation implementation study (IRIS). RMD Open. 2016;2(1):e000221. https://doi. org/10.1136/rmdopen-2015-000221.

92. Harrold LR, Harrington JT, Curtis JR, et al. Prescribing practices in a US cohort of rheumatoid arthritis patients before and after publication of the American College of Rheumatology treatment recommendations. Arthritis Rheum. 2012;64(3):630-8. https://doi.org/10.1002/art.33380.

93. Pappas DA, Gerber RA, Litman HJ, et al. Delayed treatment acceleration in patients with rheumatoid arthritis who have inadequate response to initial tumor necrosis factor inhibitors: data from the Corrona Registry. Am Health Drug Benefits. 2018;11(3):148-58.

94. Yu Z, Lu B, Agosti J, et al. Implementation of treatto-target for rheumatoid arthritis in the US: analysis of baseline data from a randomized controlled trial. Arthritis Care Res (Hoboken). 2018;70(5):801-6. https://doi.org/10.1002/acr.23343.

95. Littlejohn G, Roberts L, Arnold M, et al. A multicenter, observational study shows high proportion 
of Australian rheumatoid arthritis patients have inadequate disease control. Int $\mathrm{J}$ Rheum Dis. 2013;16(5):532-8. https://doi.org/10.1111/1756$185 X .12163$.

96. Cholapranee A, Hazlewood GS, Kaplan GG, PeyrinBiroulet L, Ananthakrishnan AN. Systematic review with meta-analysis: comparative efficacy of biologics for induction and maintenance of mucosal healing in Crohn's disease and ulcerative colitis controlled trials. Aliment Pharmacol Ther. 2017;45(10):1291-302. https://doi.org/10.1111/apt. 14030 .

97. Emamikia S, Arkema EV, Gyori N, et al. Induction maintenance with tumour necrosis factor-inhibitor combination therapy with discontinuation versus methotrexate monotherapy in early rheumatoid arthritis: a systematic review and meta-analysis of efficacy in randomised controlled trials. RMD Open. 2016;2(2):e000323. https://doi.org/10.1136/ rmdopen-2016-000323.

98. Erichsen CY, Jensen P, Kofoed K. Biologic therapies targeting the interleukin (IL)-23/IL-17 immune axis for the treatment of moderate-to-severe plaque psoriasis: a systematic review and meta-analysis. J Eur Acad Dermatol Venereol. 2020;34(1):30-8. https://doi.org/10.1111/jdv.15879.

99. Gisondi P, Di Mercurio M, Idolazzi L, Girolomoni G. Concept of remission in chronic plaque psoriasis. J Rheumatol Suppl. 2015;93:57-60. https://doi.org/ 10.3899/jrheum.150638.

100. Pavelka K, Akkoc N, Al-Maini M, et al. Maintenance of remission with combination etanercept-DMARD therapy versus DMARDs alone in active rheumatoid arthritis: results of an international treat-to-target study conducted in regions with limited biologic access. Rheumatol Int. 2017;37(9):1469-79. https:// doi.org/10.1007/s00296-017-3749-7.

101. Smolen JS, Nash P, Durez P, et al. Maintenance, reduction, or withdrawal of etanercept after treatment with etanercept and methotrexate in patients with moderate rheumatoid arthritis (PRESERVE): a randomised controlled trial. Lancet. 2013;381(9870):918-29. https://doi.org/10.1016/ S0140-6736(12)61811-X.

102. van Vollenhoven RF, Ostergaard M, Leirisalo-Repo $\mathrm{M}$, et al. Full dose, reduced dose or discontinuation of etanercept in rheumatoid arthritis. Ann Rheum Dis. 2016;75(1):52-8. https://doi.org/10.1136/ annrheumdis-2014-205726.

103. Chen MH, Lee MH, Liao HT, Chen WS, Lai CC, Tsai CY. Health-related quality of life outcomes in patients with rheumatoid arthritis and ankylosing spondylitis after tapering biologic treatment. Clin
Rheumatol. 2018;37(2):429-38. https://doi.org/10. 1007/s10067-017-3965-2.

104. Clarke K, Regueiro M. Stopping immunomodulators and biologics in inflammatory bowel disease patients in remission. Inflamm Bowel Dis. 2012;18(1):174-9. https://doi.org/10.1002/ibd. 21792.

105. Edwards CJ, Fautrel B, Schulze-Koops H, Huizinga TWJ, Kruger K. Dosing down with biologic therapies: a systematic review and clinicians' perspective. Rheumatology (Oxford). 2017;56(11):1847-56. https://doi.org/10.1093/rheumatology/kew464.

106. Haschka J, Englbrecht M, Hueber AJ, et al. Relapse rates in patients with rheumatoid arthritis in stable remission tapering or stopping antirheumatic therapy: interim results from the prospective randomised controlled RETRO study. Ann Rheum Dis. 2016;75(1):45-51. https://doi.org/10.1136/ annrheumdis-2014-206439.

107. Huang YW, Tsai TF. Remission duration and longterm outcomes in patients with moderate-to-severe psoriasis treated by biologics or tofacitinib in controlled clinical trials: a 15-year single-center experience. Dermatol Ther (Heidelb). 2019;9(3):553-69. https://doi.org/10.1007/s13555-019-0310-5.

108. Khan S, Rupniewska E, Neighbors M, Singer D, Chiarappa J, Obando C. Real-world evidence on adherence, persistence, switching and dose escalation with biologics in adult inflammatory bowel disease in the United States: a systematic review. J Clin Pharm Ther. 2019;44(4):495-507. https://doi. org/10.1111/jcpt.12830.

109. Kuijper TM, Lamers-Karnebeek FB, Jacobs JW, Hazes JM, Luime JJ. Flare rate in patients with rheumatoid arthritis in low disease activity or remission when tapering or stopping synthetic or biologic DMARD: a systematic review. J Rheumatol. 2015;42(11): 2012-22. https://doi.org/10.3899/jrheum.141520.

110. Simonini G, Ferrara G, Pontikaki I, et al. Flares after withdrawal of biologic therapies in juvenile idiopathic arthritis: clinical and laboratory correlates of remission duration. Arthritis Care Res (Hoboken). 2018;70(7):1046-51. https://doi.org/10.1002/acr. 23435.

111. Torres J, Boyapati RK, Kennedy NA, Louis E, Colombel JF, Satsangi J. Systematic review of effects of withdrawal of immunomodulators or biologic agents from patients with inflammatory bowel disease. Gastroenterology. 2015;149(7):1716-30. https://doi.org/10.1053/j.gastro.2015.08.055.

112. Ye W, Tucker LJ, Coates LC. Tapering and discontinuation of biologics in patients with psoriatic arthritis with low disease activity. Drugs. 
2018;78(16):1705-15. https://doi.org/10.1007/ s40265-018-0994-3.

113. Doherty G, Katsanos KH, Burisch J, et al. European Crohn's and Colitis Organisation topical review on treatment withdrawal ['exit strategies'] in inflammatory bowel disease. J Crohns Colitis. 2018;12(1): 17-31. https://doi.org/10.1093/ecco-jcc/jjx101.

114. Schlager L, Loiskandl M, Aletaha D, Radner H. Predictors of successful discontinuation of biologic and targeted synthetic DMARDs in patients with rheumatoid arthritis in remission or low disease activity: a systematic literature review. Rheumatology (Oxford). 2020;59(2):324-34. https://doi.org/ 10.1093/rheumatology/kez278.

115. Sekiguchi M, Fujii T, Matsui K, et al. Differences in predictive factors for sustained clinical remission with abatacept between younger and elderly patients with biologic-naive rheumatoid arthritis: results from the ABROAD study. J Rheumatol. 2016;43(11):1974-83. https://doi.org/10.3899/ jrheum. 160051 .

116. Valor L, Garrido J, Martinez-Estupinan L, et al. Identifying markers of sustained remission in rheumatoid arthritis patients on long-term tapered biological disease-modifying antirheumatic drugs. Rheumatol Int. 2018;38(8):1465-70. https://doi. org/10.1007/s00296-018-4087-0.

117. Schieir O, Tosevski C, Glazier RH, Hogg-Johnson S, Badley EM. Incident myocardial infarction associated with major types of arthritis in the general population: a systematic review and meta-analysis. Ann Rheum Dis. 2017;76(8):1396-404. https://doi. org/10.1136/annrheumdis-2016-210275.

118. Elmets CA, Leonardi CL, Davis DMR, et al. Joint AAD-NPF guidelines of care for the management and treatment of psoriasis with awareness and attention to comorbidities. J Am Acad Dermatol. 2019;80(4):1073-113. https://doi.org/10.1016/j. jaad.2018.11.058.

119. Aletaha D, Epstein AJ, Skup M, Zueger P, Garg V, Panaccione R. Risk of developing additional immune-mediated manifestations: a retrospective matched cohort study. Adv Ther. 2019;36(7): 1672-83. https://doi.org/10.1007/s12325-01900964-z.

120. Bernstein CN, Wajda A, Blanchard JF. The clustering of other chronic inflammatory diseases in inflammatory bowel disease: a population-based study. Gastroenterology. 2005;129(3):827-36. https://doi.org/10.1053/j.gastro.2005.06.021.
121. Burisch J, Jess T, Egeberg A. Incidence of immunemediated inflammatory diseases among patients with inflammatory bowel diseases in Denmark. Clin Gastroenterol Hepatol. 2019;17(13):2704-12. https://doi.org/10.1016/j.cgh.2019.03.040.

122. Cohen R, Robinson D Jr, Paramore C, Fraeman K, Renahan K, Bala M. Autoimmune disease concomitance among inflammatory bowel disease patients in the United States, 2001-2002. Inflamm Bowel Dis. 2008;14(6):738-43. https://doi.org/10. 1002/ibd.20406.

123. Conway G, Velonias G, Andrews E, Garber JJ, Yajnik $\mathrm{V}$, Ananthakrishnan AN. The impact of co-existing immune-mediated diseases on phenotype and outcomes in inflammatory bowel diseases. Aliment Pharmacol Ther. 2017;45(6):814-23. https://doi. org/10.1111/apt.13940.

124. Wu JJ, Poon KY, Channual JC, Shen AY. Association between tumor necrosis factor inhibitor therapy and myocardial infarction risk in patients with psoriasis. Arch Dermatol. 2012;148(11):1244-50. https://doi.org/10.1001/archdermatol.2012.2502.

125. Aladul MI, Fitzpatrick RW, Chapman SR. The effect of new biosimilars in rheumatology and gastroenterology specialities on UK healthcare budgets: results of a budget impact analysis. Res Social Adm Pharm. 2019;15(3):310-7. https://doi.org/10.1016/ j.sapharm.2018.05.009.

126. Jha A, Upton A, Dunlop WC, Akehurst R. The budget impact of biosimilar infliximab (Remsima ${ }^{\circledR}$ ) for the treatment of autoimmune diseases in five European countries. Adv Ther. 2015;32(8):742-56. https://doi.org/10.1007/s12325-015-0233-1.

127. Brodszky V, Rencz F, Pentek M, Baji P, Lakatos PL, Gulacsi L. A budget impact model for biosimilar infliximab in Crohn's disease in Bulgaria, the Czech Republic, Hungary, Poland, Romania, and Slovakia. Expert Rev Pharmacoecon Outcomes Res. 2016;16(1):119-25. https://doi.org/10.1586/ 14737167.2015.1067142.

128. Lee SM, Jung JH, Suh D, et al. Budget impact of switching to biosimilar trastuzumab (CT-P6) for the treatment of breast cancer and gastric cancer in 28 European countries. BioDrugs. 2019;33(4):423-36. https://doi.org/10.1007/s40259-019-00359-0.

129. Gulacsi L, Brodszky V, Baji P, Rencz F, Pentek M. The rituximab biosimilar CT-P10 in rheumatology and cancer: a budget impact analysis in 28 European countries. Adv Ther. 2017;34(5):1128-44. https://doi.org/10.1007/s12325-017-0522-y. 